\title{
IMPACT OF USING MICROBIAL FEED ADDITIVES (PROBIOTICS) IN RUMINANTS RATIONS ON DIGESTIBILITY, RUMEN FERMENTATION, MILK PRODUCTION AND PROPERTIES OF DOMIATI CHEESE \\ Ayyad, K. M. K. ${ }^{1}$; I. A. A. Abou Ayana ${ }^{2}$; M. A. Elkholany ${ }^{3}$ and M. A. M. Abd El-Hafez ${ }^{3}$ \\ ${ }^{1}$ Dairy Technology Research Department, Animal Production Research Institute, Agriculture Research Center, Ministry of Agriculture, Egypt. \\ 2 Dairy Research Department, Food Technology Research Institute, Agriculture Research Center, Ministry of Agriculture, Egypt. \\ ${ }^{3}$ Animal Production Research Institute, Agriculture Research Center, Ministry of Agriculture, Egypt
}

\begin{abstract}
This study started by nutritional evaluation (digestion coefficients and feeding value) to determine using commercial microbial additives $\mathrm{BGY}_{35}$ (yeast culture) or AVI-BAC® (lactic acid bacteria and enzymes) in the diet of Rahmani sheep feeding trails were carried out using 12 crossbred cows. Animals received the control diet (unsupplemented ration), plus probiotic $A V I-B A C \AA$ or $B G Y 35$ for the three groups $\mathrm{G}_{1}$, $\mathrm{G}_{2}$ and $\mathrm{G}_{3}$, respectively. The obtained results concluded that feeding Rahmani sheep on microbial additives increased digestion coefficients of most nutrients compared with control group $\left(G_{1}\right)$. In the same time, both $C P$ and $E E$ digestibility were significantly higher $(p<0.05)$ with $G_{2}$ and $G_{3}$ compared with $G 1$. The same positive effect was observed also with feeding values (TDN and DCP).

Treated rations $\left(\mathrm{G}_{2}\right.$ and $\left.\mathrm{G}_{3}\right)$ for sheep didn't influence in ruminal $\mathrm{pH}$ values, but ruminal total VFA's and microbial protein content were significantly higher $(p<0.05)$. Moreover, ruminal ammonia- $\mathrm{N}$ concentration was increased with the control group compared with the other groups.

The milk yield of lactating cows was higher with microbial additives $\left(G_{2}\right.$ and $\left.G_{3}\right)$ compared with control $\left(G_{1}\right)$ and the differences significant during the second period (from 61-120 days). Some positive effects were observed also as a result to using the treatments in milk content such as milk fat, protein and total solids. The treatments increased unsaturated fatty acids as well StearicC18:0 slightly increased unlike Linoleic C18:2n6 and Linolenic C18:3n3 slightly decreased. Moreover, the effect of the tested rations on somatic cell counts (SCC), $\mathrm{pH}$ value and acidity\% as milk quality were not significant. BGY35 (G3) gained the highest points followed by AVI-BAC® (G2) then the control that was the lowest organoleptic properties.
\end{abstract}

\section{INTRODUCTION}

Recently, increasing attention is paid to the use of natural products instead of chemical compounds as manipulators of rumen fermentation. However, additives must be harmless to animals and no toxic residue present in their bodies or animals products.

For many years, ruminant nutritionists and microbiologists have been interested in manipulating the microbial ecosystem of the rumen to improve feed utilization and production efficiency by domestic ruminants (Samtra and 
Karim, 2003). Addition of Saccharomyces cerevisiae live yeast cultures to ruminant diet has improved fiber digestibility and stimulated celluloytic bacteria (Dawson and Tricarico, 2002), increased the ruminal pH (Radev, 1999), total volatile fatty acid (Enjalbert et al., 1999) protozoa count ( Jouany et al., 1998), and nutrients digestibility (özsoy et al., 2013 and Kassab and Mohamed, 2013) and decreased the $\mathrm{NH}_{3}-\mathrm{N}$ (Koul et al., 1998). Also they effected percentages of different protozoa (Arakaki et al., 2000) and blood variables (Qnifade et al., 1999; and Galip et al., 2004). Generally, the manipulation of rumen microbial activity including dietary antibiotics and probiotics (bacterial and yeast culture) has been widely studied during the last 20 years. These probiotics are live microbial feed supplements which have been used as growth promoters to replace the widely used antibiotics and synthetic chemical feed supplement (Strzetelski, 1996 and Dawson, 2002).

Many researchers studied the effects of diet additives on certain physiological characteristics of dairy animals (cows, goats, sheep and buffaloes), include microbial additives for this purpose. However, they rarely studied the impact of these additives on the quality of dairy products such as Domiati cheese. Therefore, this study was conducted to investigate the effect of feeding microbial additives as yeast culture (BGY 35) and probiotic (AVI$B A C \AA$ ) on nutrient digestibility, rumen fermentation parameters and milk yield as well the effect of these additives on the quality of Domiati cheese during storing for three months.

\section{MATERIALS AND METHODS}

This study was conducted at El-Serw Experimental Research Station belonging to the Animal Production Research Institute, Agriculture Research Center, Ministry of agriculture. Yeast culture (BGY35) is a brewer's dried yeast (Saccharomyces cerevisiae) composed of $35 \%$ crude protein, $1 \%$ crude fat and $8 \%$ crude fiber and contains vitamins, amino acids and minerals. Moreover, probiotic (AVI-BAC®) as growth promoter was produced by ProByn international Inc. (USA). Witch $\mathrm{kg}$ of AVI-BAC $\AA^{\circ}$ contains lactobacillus (100g L. acidophilus, $1.0 \times 10^{8} \mathrm{CFU} / \mathrm{g}$ and L. planterum, $98 \mathrm{~g}$, $\left.9.8 \times 10^{7} / \mathrm{g}\right)$, Bifidobacterium bifidum $\left(2 \mathrm{~g}, 2.0 \times 10^{6} / \mathrm{g}\right)$, Bacillus subtilis fermentation extract $(50 \mathrm{~g})$, Asperagillus oryzae fermentation extract $(50 \mathrm{~g})$, dextrose as diluents $(70 \mathrm{~g})$ and enzymes including amylase $(25 \mathrm{u} / \mathrm{g})$, cellulose $(4.5 \mathrm{U} / \mathrm{g})$, beta-glucanase $(2.25 \mathrm{u} / \mathrm{g})$ and hemicellulase $(2.75 \mathrm{u} / \mathrm{g})$. Each trial continued for 28 days the first 21 days as preliminary period, followed by 7 days for feces collection. The animals were fed according to NRC (1985) feed allowances.

Rumen fluid samples were taken from the three rams of each group at the end of experiment using stomach tube before feeding ( 0 times) and postfeeding ( 4 and $8 \mathrm{hrs}$ ). The samples were filtered through 3 layers of gauze and their $\mathrm{pH}$ values were immediately determined Ammonia nitrogen $\left(\mathrm{NH}_{3}-\mathrm{N}\right)$ concentration was measured according to Conway (1957), total volatile fatty acids (VFA's) according to the technique described by Warner (1964) and 
microbial protein content was estimated by the method of Shultz and Shultz (1970).

In addition, nutrient digestibilities were determined using acid insoluble ash (AIA) technique of Van keulen and Young (1977).

The experimental work included two experiments:

The first experimental: Digestibility trails (on Rahmani rams).

Three groups of Rahmani rams, each of 3 animals with an average live body weight of $55.0 \mathrm{~kg}$ and average age 3 years, were used to determine digestion coefficients and some ruminal parameters. Animals were fed a diet composed of CFM and roughage (corn silage, berseem hay and rice straw) as a control diets $\left(G_{1}\right)$ with commercial yeast culture ( $\mathrm{S}$. cerevisiae) namely BGY $35\left(G_{2}\right)$ or a product of lactic acids bacteria and enzymes namely AVI$\operatorname{BAC} \circledast\left(\mathrm{G}_{3}\right)$.

The second experimental: Effect on milk yield and quality (on crossbred cows): Three groups of dairy cows, each of 4 animals with an average live body weight of $44.0 \mathrm{~kg}$ were used to study the effect of the 3 tested rations as reported earlier on daily milk yield, milk composition and quality during the first 4 month after calving (120 days). The experimental cows were divided according to LBW, parity and milk production to three experimental groups. Animal were housed under semi-open shed.

Cows in all groups were fed based on milk yield according to NRC1988. Amount of feeds were adjusted biweekly based on milk yield and body weight.

Cows in the first group were fed the control diet (unsupplemented, $G_{1}$ ), while those in the $2^{\text {nd }}$ and $3^{\text {rd }}$ groups were fed the control diets daily supplemented with $3 \mathrm{~g}$ AVI-BAC $\AA$ ( ${ }^{\circledR}$ per cow $\left(A V I-B A C \AA \AA A, G_{2}\right)$ and $20 \mathrm{~g}$ BGY35 per cow (BGY35, $\mathrm{G}_{3}$ ), respectively. Supplements of each treatment group were well mixed with the ingredients of daily amount of CFM immediately before feeding. Feeds were offered to animals in all groups twice daily during the experimental period. Cows in all groups were individually fed on different experimental diets.

Calf rennet powder (HALA) and mixed strains of Lactococcus lactis sp. Lactis and Lactococcus lactis sp. cremoris were obtained from Chr. Hansen's Lab Oritorum. A/S Copenhagen, Denmark). Salt was obtained from El-Naser Company of Alexandria.

Domiati cheese making: At the last 3 days of each period, the animals are hand milked (twice/day). The collected milk from each group was pooled and used for analysis and manufacturing of Domiati cheese according to Fahmi and Sharara (1950). All milk batches were heated to $75^{\circ} \mathrm{C} / 15 \mathrm{sec}$. and then cooled to $38^{\circ} \mathrm{C}$. The starter culture $(1 \% \mathrm{w} / \mathrm{w})$ and salt $(5 \% \mathrm{w} / \mathrm{w})$ were added to cheese milk and appropriate amount of rennet was added to achieve coagulation in $150 \mathrm{~min}$. The resultant cheeses were separately pickled in their whey and stored at $6 \pm 2^{\circ} \mathrm{C}$ for 3 month. The samples were analyzed fresh and every month of storage. Fat, total nitrogen (TN), non-protein nitrogen (NPN), soluble nitrogen (SN), Dry matter, somatic cell count, titratable acidity (TA), Ash, total solids, solid non fat, lactose, protein, amino acids, and fatty acids of milk or cheese samples were determined according 
to AOAC (2007). Total volatile fatty acids (TVFAs) were estimated as $\mathrm{ml} 0.1$ $\mathrm{N} \mathrm{NaOH} / 10 \mathrm{~g}$ cheese, according to Kosikowski (1987).

Domiati cheese was judged at fresh and every month of storage for organoleptic properties by 11 staff numbers of dairy department according to Pappas et al. (1996).

Rheological properties analysis: The curd tension (firmness) of milk curd was determined as described by Chandrasekhare et al. (1957). Syneresis (whey separation) was determined using the drainage whey $(\mathrm{ml} / 100 \mathrm{ml}$ yoghurt) as described by Hassan et al. (1999).

Data was statistically analyzed using SAS (2003). The significant differences among means were assigned according to Duncan (1955).

\section{RESULTS AND DISCUSSION}

\section{Digestibility trails:}

Digestion coefficients: The effect of the experimental rations on digestion coefficients of most nutrients and feeding values (TDN and DCP) were not significant (Table 1). The lowest values of digestion coefficients of all nutrient and feeding values were recorded with $G_{1}$ (control). In the same time, the digestion coefficients of $C P$ and $E E$ were higher $(p<0.05)$ with $G_{2}$ and $G_{3}$ compared with $G_{1}$ (control). The improvement in digestion coefficients of nutrients with feed additives may be due to the better condition of the rumen fermentation as reported by Wohlt et al. (1998) and Calsamiglia et al. (2006).

Table (1): Effect of dietary supplementation of microbial additives on digestion coefficients and feeding values.

\begin{tabular}{|l|c|c|c|}
\hline \multirow{2}{*}{ Items } & \multicolumn{3}{|c|}{ Groups } \\
\cline { 2 - 4 } & G1 (control) & G2 (AVI-BAC $\AA)$ & G3 (BGY35) \\
\hline \multicolumn{4}{|c|}{ digestion coefficients, \% } \\
\hline DM & $72.60 \pm 3.22$ & $74.03 \pm 2.65$ & $73.71 \pm 3.61$ \\
\hline OM & $70.05 \pm 2.25$ & $72.53 \pm 3.01$ & $72.15 \pm 2.07$ \\
\hline CP & $73.89 \pm 1.65^{\mathrm{b}}$ & $76.95 \pm 2.11^{\mathrm{a}}$ & $76.57 \pm 1.60^{\mathrm{a}}$ \\
\hline CF & $65.71 \pm 1.68$ & $68.23 \pm 2.19$ & $67.51 \pm 2.68$ \\
\hline EE & $66.52 \pm 3.17^{\mathrm{b}}$ & $71.15 \pm 2.63^{\mathrm{a}}$ & $70.65 \pm 1.17^{\mathrm{a}}$ \\
\hline NFE & $71.10 \pm 4.18$ & $72.93 \pm 3.69$ & $72.70 \pm 2.69$ \\
\hline \multicolumn{4}{|c|}{ Feeding values, \% } \\
\hline TDN & $65.41 \pm 1.73$ & $67.35 \pm 2.68$ & $67.03 \pm 2.15$ \\
\hline DCP & $8.15 \pm 0.18$ & $8.43 \pm 0.21$ & $8.37 \pm 0.23$ \\
\hline
\end{tabular}

$A$ and $b$ : Means having different superscripts within the same row are significantly different at $p<0.05$.

Ruminal parameters: Rumen parameters are presented in Table, 2. The maximum $\mathrm{pH}$ values were noticed pre-feeding ( 0 time) while the maximum values were observed at $4 \mathrm{hrs}$ post-feeding then it tended to increase again at $8 \mathrm{hrs}$ post-feeding for all dietary treatments. In the same time, the effect of the tested rations on $\mathrm{pH}$ values was not significant. The highest values before and after feeding $(0,4$ and $8 \mathrm{hrs})$ of ruminal ammonia- $\mathrm{N}$ were recorded with $\mathrm{G}_{1}(17.35,21.85$ and 20.05$)$ followed by $\mathrm{G}_{3}(17.15,21.37$ and 19.15$)$ and the lowest values were detected with $\mathrm{G}_{2}(16.50,20.03$ and 18.39 , respectively) 
and the differences were significant at 4 hours post-feeding only. Moreover, both ruminal total VFA's concentration and microbial protein content postfeeding ( 4 and 8 hrs) were noticeably higher with both treatments $\left(G_{2}\right.$ and $\left.G_{3}\right)$ compared with unsupplemented ration $\left(\mathrm{G}_{1}\right)$. These positive effects of both treatments (AVI-BAC $\circledast$ ) and BGY35) on most ruminal parameters was observed also by Ahmed (2001), El-Ashry et al, 2001 and Aiad et al., 2014) with farm animals ( Friesian cows, buffaloes and goats, respectively).

Table (2): Ruminal parameters for Rahmani rams fed the experimental rations.

\begin{tabular}{|l|c|c|c|c|}
\hline \multirow{2}{*}{ Items } & \multirow{2}{*}{ Hours } & \multicolumn{3}{|c|}{ Groups } \\
\cline { 2 - 5 } & 0 & G1 (control) & G2 (AVI-BAC $\AA$ ) & G3 (BGY35) \\
\hline \multirow{3}{*}{ PH values } & 4 & $6.13 \pm 0.10$ & $7.10 \pm 0.12$ & $6.95 \pm 0.15$ \\
\cline { 2 - 5 } & 8 & $6.70 \pm 0.03$ & $6.37 \pm 0.07$ & $6.33 \pm 0.16$ \\
\hline \multirow{3}{*}{$\begin{array}{l}\text { Ammonia-N } \\
\text { (mg/100ml) }\end{array}$} & 0 & $17.35 \pm 0.65$ & $6.63 \pm 0.05$ & $6.67 \pm 0.10$ \\
\cline { 2 - 5 } & 4 & $21.85 \pm 0.20^{\mathrm{a}}$ & $20.50 \pm 0.35$ & $17.15 \pm 0.51$ \\
\cline { 2 - 5 } & 8 & $20.05 \pm 0.15$ & $18.39 \pm 0.35$ & $21.37 \pm 0.18^{\mathrm{a}}$ \\
\hline \multirow{3}{*}{$\begin{array}{l}\text { Total VFA's } \\
\text { (MEq/100ml) }\end{array}$} & 0 & $8.50 \pm 0.30$ & $8.80 \pm 0.25$ & $8.75 \pm 0.25$ \\
\cline { 2 - 5 } & 4 & $11.35 \pm 0.11^{\mathrm{b}}$ & $12.40 \pm 0.20^{\mathrm{a}}$ & $12.50 \pm 0.14^{\mathrm{a}}$ \\
\cline { 2 - 5 } & 8 & $10.35 \pm 0.13^{\mathrm{b}}$ & $11.30 \pm 0.15^{\mathrm{a}}$ & $11.25 \pm 0.11^{\mathrm{a}}$ \\
\hline \multirow{2}{*}{$\begin{array}{l}\text { Microbial protein } \\
\text { (g/100ml) }\end{array}$} & 0 & $0.333 \pm 0.010$ & $0.337 \pm 0.010$ & $0.400 \pm 0.007$ \\
\cline { 2 - 5 } & 4 & $0.553 \pm 0.009^{\mathrm{b}}$ & $0.567 \pm 0.09^{\mathrm{a}}$ & $0.570 \pm 0.10^{\mathrm{a}}$ \\
\cline { 2 - 5 } & 8 & $0.470 \pm 0.008^{\mathrm{b}}$ & $0.503 \pm 0.08^{\mathrm{a}}$ & $0.500 \pm 0.10^{\mathrm{a}}$ \\
\hline
\end{tabular}

$A$ and $b$ : Means having different superscripts within the same row are significantly different at $p<0.05$.

Generally, the highest value of total VFA's, microbial protein and ammonia-N concentrations were at 4 hrs post-feeding which was reflected on lowering $\mathrm{pH}$ values at that time as reported by Ibrahim et al., 2007, Ahmed et al., 2011 El-Emam et al., 2014 with lactating Zaraibi goats.

Daily milk yield: Milk yield as $\mathrm{kg} / \mathrm{h} / \mathrm{d}$ of lactating cows during the two experimental periods (120 days) are presented in Table (3). The daily milk yield was higher with $G_{2}$ and $G_{3}$ compared with the control group $\left(G_{1}\right)$ and the differences were significant during the second period (from 61-120 day). The daily milk yield during the $1^{\text {st }}$ period was $10.19,11.73$ and $11.55 \mathrm{~kg}$ for $\mathrm{G}_{1}, \mathrm{G} 2$ and $\mathrm{G}_{3}$, respectively. The corresponding value during $2^{\text {nd }}$ period were 5.95 , 7.10 and $6.96 \mathrm{~kg}$, respectively. Similar results were observed also by Yousef et al. 1996, Putnam et al. (1997) and Ahmed et al. (2008) with using microbial additives in rations of buffaloes, cows and goats, respectively. In this respect, El-Ashry et al., (2001), Aboul-Fotouh et al. (2011) and Abd-Elaziz (2013) reported that the daily milk yield was noticeable improved as a result of using microbial additives and this might be attributed to its positive effect on digestibility of nutrients and ruminal enveromintals reported by the present study.

\section{Milk composition:}

Concerning milk composition (Table, 3 ) the data indicated that the differences among the three groups were not significant $(p<0.05)$ during the 
two experimental periods. Some positive effects were observed with the treatments groups $\left(G_{2}\right.$ and $\left.G_{3}\right)$ in both milk fat and total solids during the two experimental periods but without significant differences. Generally, the obtained values of milk constituents were within the normal range given by Putnam et al., (1997) and Aboul-Fotouh et al., (2011) for dairy cows.

Table (3): Milk production and its chemical composition of dairy cows fed the experimental rations during the two experimental periods.

\begin{tabular}{|c|c|c|c|}
\hline \multirow{2}{*}{ Items } & \multicolumn{3}{|c|}{ Groups } \\
\hline & $\mathrm{G}_{1}$ (control) & $\mathrm{G}_{2}(\mathrm{AVI}-\mathrm{BAC} \AA$ & $\mathrm{G}_{3}$ (BGY35) \\
\hline \multicolumn{4}{|c|}{ First period ( from 1: 60 days) : } \\
\hline Daily milk yield (kg/h) & $10.19 \pm 0.93$ & $11.73 \pm 1.05$ & $11.55 \pm 0.77$ \\
\hline Fat & $3.45 \pm 0.07$ & $3.61 \pm 0.05$ & $3.55 \pm 0.03$ \\
\hline Protein & $2.91 \pm 0.03$ & $2.95 \pm 0.02$ & $3.01 \pm 0.05$ \\
\hline Lactose & $4.55 \pm 0.08$ & $4.61 \pm 0.05$ & $4.63 \pm 0.07$ \\
\hline Solids non fat & $8.15 \pm 0.07$ & $8.27 \pm 0.09$ & $8.36 \pm 0.06$ \\
\hline Total solids & $11.60 \pm 0.11$ & $11.88 \pm 0.12$ & $11.91 \pm 0.09$ \\
\hline Ash & $0.69 \pm 0.01$ & $0.71 \pm 0.01$ & $0.72 \pm 0.01$ \\
\hline Somatic cell count $\times 10^{3}$ & $151 \pm 15$ & $139 \pm 11$ & $145 \pm 17$ \\
\hline $\mathrm{pH}$ value & $6.59 \pm 0.01$ & $6.65 \pm 0.01$ & $6.63 \pm 0.00$ \\
\hline Acidity, \% & $0.160 \pm 0.002$ & $0.167 \pm 0.001$ & $0.169 \pm 0.001$ \\
\hline \multicolumn{4}{|c|}{ Second period (from 61:120 days) : } \\
\hline Daily milk yield ( $\mathrm{kg} / \mathrm{h})$ & $5.95 \pm 0.45^{b}$ & $7.10 \pm 0.57^{\mathrm{a}}$ & $6.97 \pm 0.31^{\mathrm{a}}$ \\
\hline Fat & $3.71 \pm 0.09$ & $3.77 \pm 0.07$ & $3.75 \pm 0.03$ \\
\hline Protein & $2.93 \pm 0.05$ & $2.99 \pm 0.03$ & $3.03 \pm 0.05$ \\
\hline Lactose & $4.60 \pm 0.08$ & $4.63 \pm 0.05$ & $4.67 \pm 0.07$ \\
\hline Solids non fat & $8.23 \pm 0.05$ & $8.34 \pm 0.08$ & $8.43 \pm 0.09$ \\
\hline Total solids & $11.94 \pm 0.08$ & $12.11 \pm 0.09$ & $12.18 \pm 0.11$ \\
\hline Ash & $0.70 \pm 0.01$ & $0.72 \pm 0.00$ & $0.73 \pm 0.01$ \\
\hline Somatic cell count $\times 10^{3}$ & $135 \pm 13$ & $119 \pm 17$ & $131 \pm 12$ \\
\hline $\mathrm{pH}$ value & $6.67 \pm 0.01$ & $6.65 \pm 0.00$ & $6.69 \pm 0.01$ \\
\hline Acidity, \% & $0.162 \pm 0.001$ & $0.165 \pm 0.002$ & $0.164 \pm 0.001$ \\
\hline
\end{tabular}

$A$ and $b$ : Means having different superscripts within the same row are significantly different at $p<0.05$.

Somatic cell counts and milk quality: The effect of the experimental rations on somatic cell counts (SCC) and milk quality such as $\mathrm{pH}$ and acidity $\%$ were not significant as shown in Table (3). Moreover, the flavor and colour of the different group were not affected by treatments. The highest value of acidity\% (0.169) was recorded with $G_{3}$ while the lowest value was detected with $G_{1}(0.160)$ and the differences were not significant.

Table 5: Some fatty acids of milk fat contents of dairy cows fed the experimental rations during the two experimental periods.

\begin{tabular}{|l|c|c|c|c|c|}
\hline \multirow{2}{*}{ Treatments } & \multicolumn{5}{|c|}{ Fatty acids } \\
\cline { 2 - 7 } & $\begin{array}{c}\text { Palmitic } \\
\text { C16:0 }\end{array}$ & $\begin{array}{c}\text { Stearic } \\
\text { C18:0 }\end{array}$ & $\begin{array}{c}\text { Oleic } \\
\text { C18:1n9 }\end{array}$ & $\begin{array}{c}\text { Linoleic } \\
\text { C18:2n6 }\end{array}$ & $\begin{array}{c}\text { Linolenic } \\
\text { C18:3n3 }\end{array}$ \\
\hline Control & $28.56 \pm 0.794$ & $10.57 \pm 1.962$ & $21.35 \pm 1.238$ & $3.63 \pm 0.149$ & $0.48 \pm 0.005$ \\
\hline AVI-BAC $\AA$ & $25.0 \pm 0.695$ & $11.0 \pm 2.04$ & $24.7 \pm 1.432$ & $2.1 \pm 0.086$ & $0.21 \pm 0.003$ \\
\hline BGY35 & $27.2 \pm 0.757$ & $12.62 \pm 2.34$ & $22.3 \pm 1.177$ & $2.54 \pm 0.104$ & $0.24 \pm 0.002$ \\
\hline
\end{tabular}


Similar results were observed also by Ahmed et al. (2008). They found that milk quality ( $\mathrm{pH}$ and acidity \%) and somatic cell counts were not significantly effect as a result to using of microbial additives in lactating goats rations.

Data in Table (5) indicated supplementing cow's diets with AVI-BAC $\AA$ or BGY35 significant $(P<0.05)$ affected fatty acids milk contents, Palmitic C16:0, Stearic C18:0, Oleic C18:1n9, Linoleic C18:2n6 and Linolenic C18:3n3. Oleic C18:1n9 and Stearic C18:0 increased by adding AVI-BAC ${ }^{8}$ or BGY35 compared with the control whilst Palmitic C16:0, Linoleic C18:2n6 and LinolenicC18:3n3 decreased against the control. According to the World Health Organization, evidence is "convincing" that consumption of palmitic acid increases risk of developing cardiovascular diseases (WHO, 2003). Also, Oleic acid is a common monounsaturated fat in human diet. Monounsaturated fat consumption has been associated with decreased lowdensity lipoprotein (LDL) cholesterol, and possibly increased high-density lipoprotein (HDL) cholesterol. Despite the slight increase in Stearic acid C18:0, it is undesirable. Likewise the decline in Linoleic C18:2n6 and Linolenic C18:3n3 is undesirable as well

Table (6): Milk fatty acid profile of dairy cows fed the experimental rations during the two experimental periods.

\begin{tabular}{|l|c|c|c|c|}
\hline \multirow{2}{*}{ Fatty acids } & \multirow{2}{*}{ Name } & \multicolumn{3}{|c|}{ Relative distribution \% } \\
\cline { 3 - 5 } & & Control & AVI-BAC 8 & BGY35 \\
\hline C6:0 & Caproic acid & 1.11 & 1.2 & 0.90 \\
\hline C8:0 & Caprlyic acid & 4.72 & 4.63 & 4.87 \\
\hline C10:0 & Capric acid & 2.46 & 2.50 & 2.0 \\
\hline C11:0 & & - & 0.50 & - \\
\hline C12:0 & Lauric acid & 2.22 & 2.45 & 2.44 \\
\hline C14:0 & Myristic acid & 8.6 & 9.71 & 10.4 \\
\hline C14:1ù7 & Myristioleic acid & 0.26 & 0.2 & 0.27 \\
\hline C14:1 ù5 & & 0.76 & 0.80 & 0.72 \\
\hline C15:0 & Pentadecanoic acid & 2.39 & 2.74 & 3.1 \\
\hline C16:1 ù9 & Palmitoleic acid & 0.24 & 0.40 & 3.3 \\
\hline C16:1 ù7 & & 1.34 & 1.10 & 0.66 \\
\hline C16:1 ù5 & & 0.78 & 0.43 & 0.70 \\
\hline C16:3 ù4 & Hexagonic acid & 0.32 & 0.46 & 0.34 \\
\hline C17:0 & Heptadecanoic acid & 2.0 & 2.52 & 2.55 \\
\hline C18:1ù7 & Vaccinic acid & 2.36 & 2.32 & 3.24 \\
\hline C18:1 ù5 & & 0.85 & 0.78 & 1.01 \\
\hline C18:2 ù7 & & 0.67 & 0.60 & 0.64 \\
\hline C18:2 ù4 & & - & - & 0.23 \\
\hline C18:3 ù6 & Gamma Linolenic acid & 0.48 & 0.20 & 0.23 \\
\hline C18: 3 ù4 & & - & 0.20 & \\
\hline C18: 4 ù3 & Linolenic acid & 0.63 & 0.70 & 0.72 \\
\hline C20:0 & Arachidic acid & 0.23 & 0.20 & 0.25 \\
\hline Non identified & & 2.99 & 2.86 & 1.10 \\
fatty acids & & & & \\
\hline
\end{tabular}


Data presented in Table (6) indicated that cow's diets supplemented with AVI-BAC ${ }^{8}$ or BGY35 significant $(P<0.05)$ increased both of $\mathrm{C} 11: 0$, Lauric acid C12:0, Myristic acid C14:0, Pentadecanoic acidC15:0, C16:1 w9 Palmitoleic acid, C17:0 Heptadecanoic acid, C18: $3 \omega 4$, and C18: $4 \omega 3$

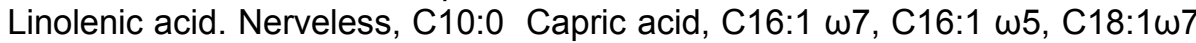
Vaccinic acid, C18:2 $\omega 7$ and C18:3 $\omega 6$ Gamma Linolenic acid decreased by previous treatments. On the other hand, adding of AVI-BAC $\AA$ to cows' diets increased C6:0 Caproic acid and C14:1 $\omega 5$. At the same time addition of BGY35 to cows' diets increased C8:0 Caprlyic acid, C18:1w7 Vaccinic acid, C18:1 $\omega 5$ and Arachidic acid C20:0. From these data, the good effect of these bio- additives (AVI-BAC $\AA$ or BGY35) appeared by increasing the level of health fatty acids (unsaturated FA). BGY35 improved the level these acids more than $\mathrm{AVI}-\mathrm{BAC}{ }^{\mathrm{B}}$. These additives had almost equal effect on saturated fatty acids

Table 7: Some chemical properties of milk used manufacturing Domiati cheese.

\begin{tabular}{|l|c|c|c|c|c|c|c|}
\hline Treatments & Acidity & pH & TS\% & Fat\% & TN\% & Lactose\% & Ash\% \\
\hline Control & 0.17 & 6.63 & 11.51 & 3.7 & 2.66 & 4.62 & 0.7 \\
\hline AVI-BAC $\AA$ & 0.17 & 6.62 & 11.84 & 4.0 & 2.75 & 4.83 & 0.7 \\
\hline BGY35 & 0.17 & 6.62 & 11.96 & 3.8 & 2.76 & 4.87 & 0.7 \\
\hline
\end{tabular}

Milk obtained from cows was analyzed; data presented in Table (7) shows the chemical properties. Acidity, $\mathrm{pH}$ and Ash were similar in AVI$B A C \Theta, B G Y 35$ treatments and control samples. Milk samples of treatments $\mathrm{AVI}-\mathrm{BAC} \AA$ and $\mathrm{BGY} 35$ were higher fat, TN, lactose and TS\% than control. It is expected; this reflected in the yield of Domiati cheese manufactured as well its chemical composition.

Table (8): effect of different rations feeding cows on rheological properties of milk curd

\begin{tabular}{|l|c|c|c|c|c|c|}
\hline Treatments & $\begin{array}{c}\text { Rennet } \\
\text { coagulation } \\
\text { time (sec) }\end{array}$ & Curd tension & \multicolumn{4}{|c|}{ Curd syneresis time (min) } \\
\cline { 4 - 7 } & 176 & 23.51 & 2.26 & 5.96 & 6.90 & 7.27 \\
\hline Control & 172 & 24.62 & 4.29 & 5.83 & 6.87 & 7.10 \\
\hline AVI-BAC $\circledast$ & 171 & 24.41 & 4.23 & 5.95 & 6.89 & 7.20 \\
\hline BGY35 & &
\end{tabular}

Rheological characteristics of curd depend on the milk components, protein, fat, solids and solids not fat and ash. In this study all these compounds increased which reflected on the rheological properties. Rennet coagulation time (sec) decreased in AVI-BAC $\AA$; BGY35 treatments compared with control (176 sce.) unlike Curd tension took an opposite direction. Rennet coagulation time (sec) and curd tension were close together largely in treatments. Concerning curd syneresis time (min), AVI-BAC ${ }^{8}$; BGY35 treatments achieved a decline in curd syneresis time at the all intervals except after $10 \mathrm{~min}$. Curd syneresis was nearly double (4.29 and 4.23) in AVI-BAC ${ }^{\circledR}$; BGY35 treatments, respectively compared with control (2.26). These results could be attributed to the rearrangements, within the network produced by attractive forces between individual casein particles or clusters micelles leading to additional intermolecular bonds and, therefore, to a 
contraction of the gel and the expulsion of whey, which was favoured by change in $\mathrm{pH}$ values (Walstra et al., 1985).

\section{Chemical Composition of Domaiti Cheese}

In general, TS\%, Acidity\%, Fat/DM\%, TN/DM\%, SN/TN\%, Amino acid\%, TVFAs gradually increased along storage period (Table 9). The two treatments were slightly higher TS\% than control, but there in not a clear difference between AVI-BAC $\AA$ and BGY35 treatments was detected. The acidity increased along storage period to reach 2.33, 2.37 and 2.39 for control, AVI-BAC $\AA$ and BGY35, respectively, the $\mathrm{pH}$ - values took an opposite direction. With regard Fat/DM\%, the two treatments (AVI-BAC® and BGY35) were slightly higher than the control; these treatments didn't record obvious differences in Fat/DM\%. It was natural that this ratio increases with the length of storage. Microbial additives influenced protein proteolysis of cheese during cold storage, TN/DM\%, SN/TN\% and Amino acid\% increased in both AVI$B A C \AA$ and BGY35 compared with the control. Regarding TVFAs, the control was lower than the two treatments (AVI-BAC ${ }^{\circ}$ and BGY35) this decline was negligible as well the difference between the treatments was limited.

Table (9): Some chemical properties of Domiati cheese during cold storage period as affected by microbial additives (AVI-BAC $\AA$ and BGY35).

\begin{tabular}{|c|c|c|c|c|c|c|c|c|c|}
\hline \multirow[b]{2}{*}{ Group } & \multirow{2}{*}{$\begin{array}{l}\text { Storage } \\
\text { period }\end{array}$} & \multicolumn{8}{|c|}{ Chemical analysis } \\
\hline & & $\begin{array}{l}\text { TS } \\
\%\end{array}$ & \begin{tabular}{|c|} 
Acidity \\
$\%$
\end{tabular} & $\mathrm{pH}$ & $\begin{array}{c}\text { Fat/DM } \\
\%\end{array}$ & $\begin{array}{c}\text { TN/DM } \\
\%\end{array}$ & $\begin{array}{c}\text { SN/TN } \\
\%\end{array}$ & $\begin{array}{l}\text { Amino } \\
\text { acid\% }\end{array}$ & TVFAs \\
\hline \multirow{4}{*}{ control } & Zero & 34.2 & 0.18 & 6.57 & 36.2 & 4.6 & 9.7 & 0.024 & 7.1 \\
\hline & Month & 38.1 & 1.58 & 5.12 & 42.4 & 5.9 & 12.6 & 0.027 & 11.1 \\
\hline & 2 month & 40.6 & 2.13 & 4.55 & 44.2 & 6.3 & 14.5 & 0.030 & 12.8 \\
\hline & 3 month & 42.8 & 2.33 & 4.19 & 44.2 & 6.8 & 17.3 & 0.040 & 14.1 \\
\hline \multirow{4}{*}{$\begin{array}{c}\text { AVI- } \\
\text { BAC }\end{array}$} & Zero & 33.9 & 0.18 & 6.58 & 36.8 & 4.8 & 9.8 & 0.024 & 7.3 \\
\hline & Month & 37.2 & 1.58 & 5.10 & 43.1 & 6.3 & 12.9 & 0.029 & 11.5 \\
\hline & 2 month & 41.8 & 2.14 & 4.52 & 45.0 & 6.6 & 14.8 & 0.031 & 13.1 \\
\hline & 3 month & 43.2 & 2.37 & 4.13 & 44.9 & 7.1 & 17.7 & 0.043 & 14.5 \\
\hline \multirow{4}{*}{ BGY35 } & Zero & 34.4 & 0.18 & 6.55 & 36.9 & 4.7 & 9.8 & 0.025 & 7.5 \\
\hline & Month & 39.6 & 1.59 & 5.09 & 43.4 & 6.5 & 13.0 & 0.031 & 12.0 \\
\hline & 2 month & 41.7 & 2.14 & 4.50 & 45.3 & 6.9 & 15.1 & 0.035 & 13.5 \\
\hline & 3 month & 43.2 & 2.39 & 4.11 & 45.1 & 7.4 & 18.1 & 0.048 & 14.9 \\
\hline
\end{tabular}

Organoleptic Properties: It seems from the data given in Table (10) that the all fresh Domiati cheese had nearly the same scoring point for flavour, body \& texture, the general appearance and the total points. The resultant cheese had a good body and texture (soft, smooth and lubricity texture) and pleasant creamy flavour. However, a little change was observed in cheese quality during storage period (2 month), except the body was firm comparable with fresh cheese. In general, quality of samples increased with increasing the storage period, the total points recorded the highest scores $(91.7,94.1$ and 95.6) after 3 months for the control, AVI-BAC $\AA$ and BGY35, respectively.

As ripening advanced (3 month), the flavour, body \& texture and appearance of cheese were improved. This may be contributed to the high content of soluble nitrogen serve as a precursor of certain flavour 
compounds. AVI-BAC ${ }^{\circledR}$ and BGY35 treatments had greater points than control and at the same time BGY35 treatment was better than AVI-BAC $\circledast$

Table (10): Effect of supplementing diets with microbial additives on sensory properties of Domiati cheese produced from cows' milk during cold storage period

\begin{tabular}{|l|c|c|c|c|c|}
\hline \multirow{2}{*}{ Group } & $\begin{array}{c}\text { Store } \\
\text { period }\end{array}$ & $\begin{array}{c}\text { Aberrance } \\
\mathbf{( 1 0 )}\end{array}$ & $\begin{array}{c}\text { Body \&texture } \\
\mathbf{( 4 0 )}\end{array}$ & $\begin{array}{c}\text { Flavor } \\
\mathbf{( 5 0 )}\end{array}$ & $\begin{array}{c}\text { Total } \\
\mathbf{( 1 0 0 )}\end{array}$ \\
\hline \multirow{4}{*}{ control } & Zero & 8.5 & 34.8 & 44.0 & 87.3 \\
\cline { 2 - 6 } & Month & 8.6 & 35.5 & 45.2 & 89.9 \\
\cline { 2 - 6 } & 2 month & 8.4 & 36.4 & 44.8 & 89.9 \\
\cline { 2 - 6 } & 3 month & 8.7 & 37.1 & 45.8 & 91.7 \\
\hline \multirow{3}{*}{$\begin{array}{c}\text { BVI- } \\
\text { BACB }\end{array}$} & Zero & 8.7 & 34.5 & 44.1 & 87.3 \\
\cline { 2 - 6 } & Month & 8.5 & 36.2 & 44.8 & 89.5 \\
\cline { 2 - 6 } & 2 month & 8.6 & 37.6 & 45.2 & 91.4 \\
\cline { 2 - 6 } BGY35 & 3 month & 9.0 & 38.8 & 46.3 & 94.1 \\
\cline { 2 - 6 } & zero & 8.5 & 35.1 & 44.2 & 87.8 \\
\cline { 2 - 6 } & Month & 8.7 & 36.9 & 45.8 & 91.4 \\
\cline { 2 - 6 } & 2 month & 8.9 & 37.2 & 46.3 & 92.4 \\
\cline { 2 - 6 } & 3 month & 9.2 & 39.8 & 46.6 & 95.6 \\
\hline
\end{tabular}

\section{REFERENCES}

Aboul-Fotouh G.E.; S.M. Allam; A.M. El-Gaafarawy, O.A. El-Zelaky and A.M Abdel-Hafeez (2011). productive and reproductive performance of dairy cows fed corn silage without or with some microbial additives Egypation J. Nutrition and Feeds 14 (3): 393-408,

Abd El-Aziz, M, Kholif SM, Morsy TA. Buffalo's milk composition and its fat properties as affected by feeding diet supplemented with flaxseed or fibrolytic enzymes in early lactation. J Life Sci 2012; 4: 19-25.

Ahmed, M. E., A. M. Abd El-Gwad, E. I. Shehata and S. A. Tawfik (2011). Influence of using feed forage in different forage as fresh, silage and hay on blood profile and carcass quality of growing Rahmani sheep. Egyptian J. of sheep and goat Sci., 6 (2) : 25.

Ahmed, M. E., E. I. Shehata, F. A. Ibrahim, K. M. Aiad and O. A. El-Zalaky (2008). Milk production and quality of dairy Zaraibi goats fed Trifolium alexandarinum ( $1^{\text {st }}$ cut) silage with some crop residues. Egyptian J. of sheep and goat Sci., Vol. 3(2):27-40.

Ahmed, M.E.; Fathia A. Ibrahim; Fatten F. Abou Ammo and Ahlam A. ElShewy (2001). Influence of using folic acid on lactating Zaraibi goats' performance., J. Agric. Sci. Mansoura Univ., 26:6745.

AOAC, (2007): International Official Methods of Analysis. $20 \mathrm{Ed}$. Gaithersburg, MD. USA.

Arakaki, L.C.; R.C. Stahringer ; J. E. Garrett and B. A. Dehority( 2002). The effects of feeding monensin and yeast culture, alone or combination , on the concentration and generic composition of rumen protozoa in stears fed on low-quality pasture supplemented with increasing levels of concentrate. Animal Feed Science and Technology, 84: 121:127. 
Calsamiglia, S., Castillejos, L. and Busquet, M. 2006. Alternatives to antimicrobial growth promoters in cattle. In Garnworthy, P C, Wiseman, $\mathrm{J}$ : Recent Advances in Animal Nutrition, Nottingham p. 129-167

Chandrasekhare, M. R.; Swaminathan, D. S. B. and Subramanyam, V. (1957): Effect of different treatments on curd tension. J. Food Sci. 6:226-231.

Conway, E.F.(1957). Micro diffusion Analysis and Volumetric Error. Rev. Ed. Lock Wood, London.

Dawson, K. A. and J. Tricarico (2002). The evaluation of yeast culture 20 years of research. Oroceedings of Alltech's $16^{\text {th }}$ Annual Symposium, Alltech Technical Publications, European, Middle eastern and African Lecture Tour.

Duncan, D. B. (1955). Multiple Range and Multiple F-test Biometrics, 11:1-42.

El-Ashry, M.A.; Kholif, A.M.; El-Alamy, H.A. and El-Hamamsy, T.A. 2001a. Effect of different yeast cultures supplementation to diet on the productive performance of lactating buffaloes. Egypt. J. Nutr. and Feeds, 4: 21.

El-Ashry, M.A.; Motagally, Zeba, A. and Maareck, Y.A. 2001b. Effect of live dried yeast and yeast culture on performance of growing buffalo calves. Egypt. J. Nutr. and Feeds, 4(Special Issue): 607.

El-Emam G. I., Y.H. Hafez, H. Bahery, E.I. Khalifa, E. I. Shehata and M. E. Ahmed (2014). Growth performance and some rumen and blood parameters of growing Rahmani lambs fed diets containing Triticale and berseem silages and their mixture. Egyptian J. Sheep and Goat Sci., 9(1).

Enjalbert, F.; J. E. Garrett; R. Moncoulon; C. Bayourthe and P. Chicoteau (1999). Effects of yeast culture ( Saccharomyces cerevisiae) on ruminal digestion in non-lactating dairy cows. Animal Feed and Science Technology, 76: 195-206.

Fahmi, A.H. and H.A. Sharara, 1950. Studies on Egyptian domiati cheese. J. Dairy Res., 17: 312-312.

Galib, N.; C. Aydin; I. I. Turkmen; M. Y. Yalcand and H. Biricik (2004). Effects of supplemental yeast culture on blood parameters. Indian Veternary Journal, 81: 1235- 1238.

Hassan, A. M.; Helmy, A. and Enab, A. K. (1999): Utilization of some local polysaccharide in manufacturing of yoghurt. Egyptian J. Dairy Sci. 27:281-289.

Jouany, J. P.; F. Mathieu; J. Senaud; J. Bohatier; G. Bertin; and M. Mercier (1998). The effect of Saccharomyces cerevisiae and Aspergillus oryzae on the digestion of the cell wall fraction of a mixed diet in defaunated and refaunated sheep rumen. Reproduction Nutrition Development, 38: 401-416.

Kassab, A. Y. and A. A. Mohamed (2013). Effects of dietary live dried yeast on some physiological responses and productive performances in Sohage ewes. Egyptian H. Nutrition and Feeds, 16(2) : 213-223.

Koskowiski, F. V. (1987): Cheese and Fermented Milk Food. 2nd Ed Edward Brothers. Inc. Ann, Arbor, Michigan USA. 
Koul, V.; U. Kumar; V. K. Sareen; S. Singh (1998). Mode of action of yeast culture (Yea-Sacc 1026) for stimulation of rumen fermentation in buffalo calves. Journal of the Science of Food and Agriculture, 77: 407413.

NRC (1985). Nutritional requirements of domestic animals. Nutrient requirements of sheep National Research Council, Washington.

NRC, 1988. Nutrient Requirements of Dairy Cattle. 6th rev. ed. National Research Council (U.S.A.). Subcommittee on Dairy Cattle Nutrition. Washington: National Academy of Sciences.

Onifade, A.A.; R. I. Obiyan; E. Onipede; D.O. Asejumo; O.M. Babatunde (1999).Assessment of the effects of supplementing rabbit diets with a culture of Saccharomyces cerevisiae using growth performance, blood composition and clinical enzyme activates. Animal Feed and Science Technology,. 77: 25-32.

Özsoy, B.; S. Yalcin; Z. Erdogan; Z. Cantekin and T. Aksu(2013). Effects of dietary live yeast culture on fattening performance on some blood and rumen fluid parameters in goats. Revus Med.Vet., 164, 5, 263-271.

Pappas, G.P., E. Kondlyi, L.P. Voutsinas and H. Mallatou, 1996. Effect of starter level, draining time and aging on the physico-chemical organoleptic and reheological properties of feta cheese. J. Soc. Dairy Technol., 49: 73-73.

Putnam, D. E., C. G. Schwab, M. T. Socha, N. L. Whiteouse, N. Kierstead and B. D. Garthwaite, (1997). Effect of yeast culture in the diets of early lactating dairy cows on ruminal fermentation and passage of nitrogen fractions and amino acids to the small intestine. J. Dairy Sci., 80:374.

Radev, V.. (1999). Influence og the yeast culture (Yea-Sacc 1026) on the rumen metabolism in sheep Bulgarian Journal of Agriculture Science, 5: 663-668.

Santra A. and S. A. Karim (2003): Rumen Manipulation to Improve Animal Productivity, A. Santra. Central Sheep and Wool Research Institute, Avikanagar - 304501

SAS Institute (2003). SAS/STATR User's Guide: statistics. Ver. 9.1, SAS Institute Inc., Cary, NC, USA.

Shultz, T.A. and E. Shultz (1970). Estimation of rumen microbial nitrogen by three analytical methods. J. Dairy Sci , 53:781.

Strzetelski, J. (1996). Modern principles and methods of fattened cattle nutrition. Instyut Zootechniki biuletyn digestibility studies. J. Anim. Sci.., 47:2.

Van keulen, and P. A. Young. 1977 . Evaluation of acid insoluble ash as a natural marker in ruminant digestibility studies. J. Animal Sci. 44: 282287.

Walstra, P., H.J.M. Van Dijk and T.J. Geurts, 1985. The syneresis of curd. 1 General consideration and literature review. Neth. Milk Dairy J., 39: 209-246.

Warner, A.C.I. (1964). Production of volatile fatty acids in the rumen, methods of measurements. Nutr. Abst. \& Rev., 34: 339. 
WHO Technical Report Series 916, "Diet, Nutrition and the Prevention of Chronic Diseases",Report of a Joint WHO/FAO Expert Consultation, World Health Organization, Geneva, 2003, p. 88

Wohlt, J.E.; Corcione, T.T. and Zajac, P.K. 1998. Effects of yeast on feed intake and performance of cows fed diets based on corn silage during early lactation. J. Dairy Sci. 81:1345-1352.

Yousef, H. M., K. A. El-Masry and A. I. Aboulnaga, (1996). Effect of dried live yeast supplement on haemobiochemical levels and milk production responses of lactating buffaloes under hot summer conditions in Egypt. Egyptian J. Anim. Prod., 33:11.

تأثير استخدام الاضافات الميكروبية (بروبايوتك) في علائق المجترات علي الهضم

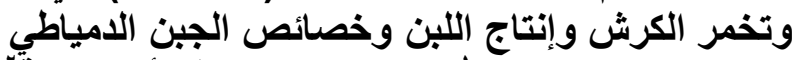

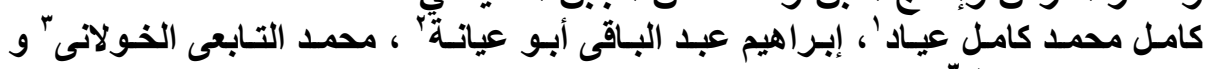

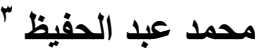

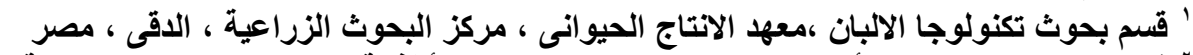

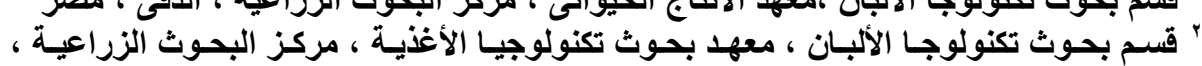

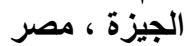

r معهد بحوث الاتتاج الحيوانى ، مركز البحوث الزراعية ، وزارة الزراعة ، مصر

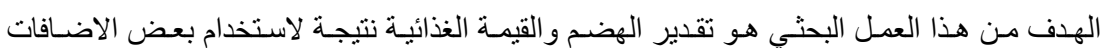

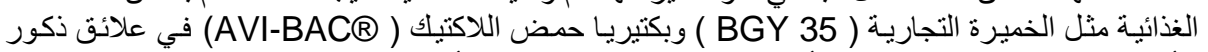

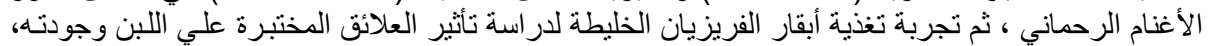

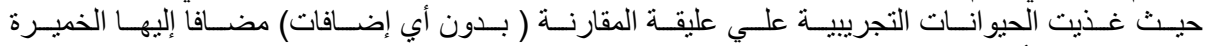

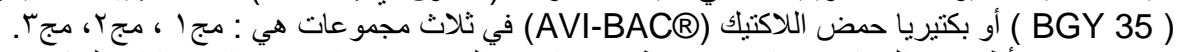

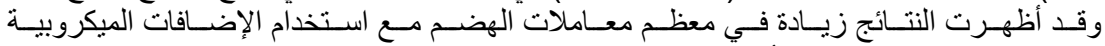

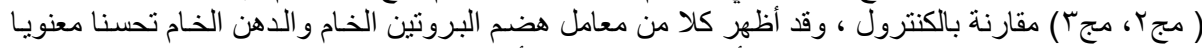

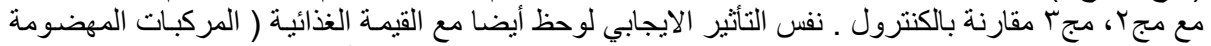

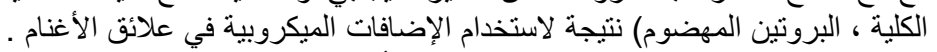

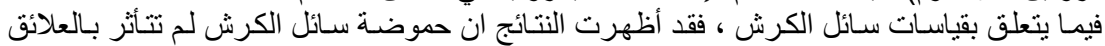

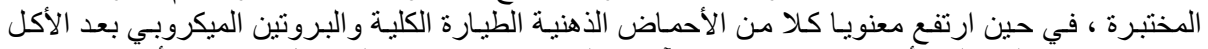

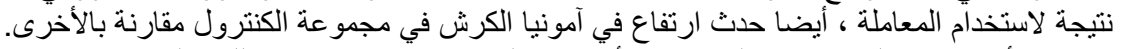

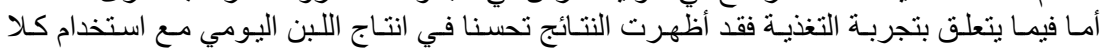

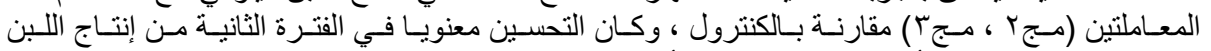

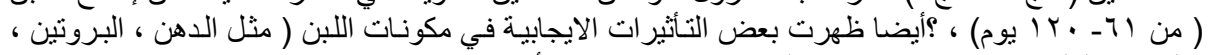

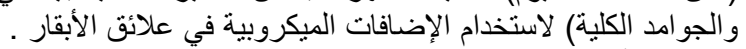

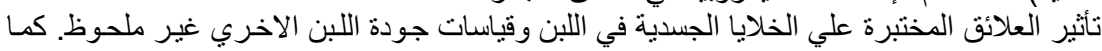

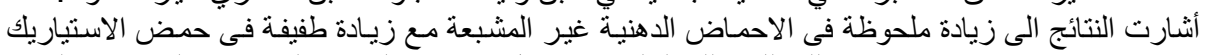

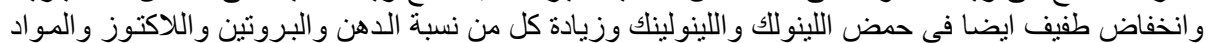

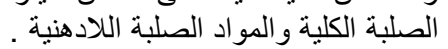

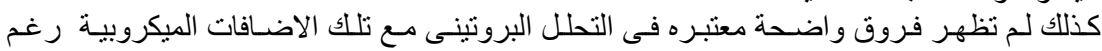

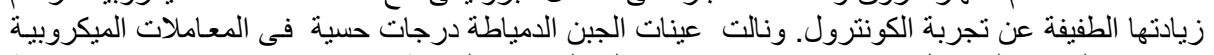

درجات اعلى من الكترول ، حيث حقق BGY35 اعلى الدرجات الحسية تلاه

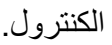

